14. Anisimov O., Symonenko V., Cherniaiev O., Shustov O. (2018). Formation of safety conditions for development of deposits by open mining. E3S Web of Conferences, vol. 60, pp. 00016. https://doi:10.1051/e3sconf/20186000016

15. Fedoniuk V. V., Volianskyi V. O., Fedoniuk M. A. (2016). Porivnialnyi ekonomichnyi analiz provedennia rekultyvatsii riznykh vydiv na porushenykh zemliakh [Comparative economic analysis of the reclamation of different species on disturbed lands]. Actual Problems of the Economy, no. 9, pp. 203-212.

\title{
THE RESEARCH OF TECHNOLOGICAL PROCESS OF GRAIN EXTRUSION WITH VEGETABLE COMPONENTS
}

\section{Ivan Ulianich ${ }^{1}$ \\ Igor Didenko $^{2}$}

DOI: https://doi.org/10.30525/978-9934-588-13-6-18

According to scientists, most vegetable plants for their economic purpose provide valuable products that should be used as a food and feed. Many vegetable plants have a large amount of nutrients and vitamins, preserving, antiseptic and bactericidal properties, which is extremely important for improving the quality of feed [1-7].

The purpose of the experiment. To develop optimal indicators of technological process of grain extrusion with vegetable components on the basis of multivariate experiment.

Research methodology. The experimental part was performed at the Department of Grain Storage and Processing Technology and at the Scientific Laboratory of Mass Analysis (attestation № AO6-203 of 25.10.16) of Uman NUS. The research were conducted in accordance with conventional methods. The technological process of grain extrusion with beet was adopted as the object of research. The data obtained was processed using Microsoft Excel applications and STATISTICA for Windows software.

The planning of the experiment was carried out by the method of steep ascent, or the Box-Wilson method, with the subsequent construction of a mathematical model of the process. Based on the chosen plan, we built a model that corresponds to the review under consideration, and used known methods of finding the extremum to find the values of the factors for which the selected objective function defined in the model will be extreme. If the

\footnotetext{
${ }^{1}$ Uman National University of Horticulture, Ukraine

${ }^{2}$ Uman National University of Horticulture, Ukraine
} 
found values of the factors corresponding to the extreme point lie on the boundary of the applied plan, the planning area either shifts or expands and a new model is built, after which the search for the extremum is repeated.

We used the following components: grain content $\left(x_{2}\right)$, beet content $\left(x_{1}\right)$ in planning, conducting and processing the results of a multifactorial experiment to formulate and solve an optimization problem. The experiment plan is shown in Table 1. Two experiments were implemented at each point of the plan. The variables $x_{i}(i=1,2, \ldots \mathrm{q})$ of such systems are the proportions (relative content) of the $i$-components of the mixture and correspond to the condition $\sum x_{i}=1\left(x_{i} \geq 0\right)$.

Table 1

Experiment planning matrix and parameter definition

\begin{tabular}{|c|c|c|c|}
\hline № & $\begin{array}{c}\text { Beet content } \\
\left(\boldsymbol{x}_{\mathbf{1}}\right)\end{array}$ & $\begin{array}{c}\text { Grain content } \\
\left(\boldsymbol{x}_{\mathbf{2}}\right)\end{array}$ & $\begin{array}{c}\text { Dependent } \\
\text { variable }\end{array}$ \\
\hline 1. & 2,5 & 97,5 & $y_{1}$ \\
\hline 2. & 5,0 & 95,0 & $y_{1}$ \\
\hline 3. & 10,0 & 90,0 & $y_{1}$ \\
\hline 4. & 15,0 & 85,0 & $y_{1}$ \\
\hline 5. & 20,0 & 80,0 & $y_{1}$ \\
\hline 6. & 22,5 & 77,5 & $y_{1}$ \\
\hline
\end{tabular}

Research results. A multifactorial experiment was conducted to develop and introduce into the production process of grain extrusion with vegetable components. During the examination of each object of the study distinguished input actions affecting the system and the corresponding reactions of the system. The parameters of influence on the system are called factors, the response of the system to the external influence is called the response, parameter or criterion of optimization. There are certain requirements for response function and optimization factors.

As the optimization criterion, which best characterizes the object of study, the specific energy intensity of the extrusion process, taking into account the degree of grinding and the quality of the crushed particles, is selected:

$$
E=\frac{N_{c} \cdot K_{\kappa}}{Q \cdot \lambda} \rightarrow \min
$$

$\mathrm{kJ} / \mathrm{kg}$,

where $N_{c}$ - the total power, $\mathrm{kW} ; K_{\kappa}$ - dimensionless quality factor; $Q$ - productivity, $\mathrm{kg} / \mathrm{h} ; \lambda$ - the degree of grinding.

The proposed assessment (1) allows us to objectively determine the specific energy intensity of the feed extrusion process at different degrees of grinding and 
quality of crushed particles and more accurately characterize the degree of perfection of the work process. The multifactor experiment was carried out in order to obtain a mathematical model of the technological process of extrusion and to determine the optimal parameters that ensure the minimum energy intensity of the process according to the specified quality indicators of feed.

For the multivariate experiment, the significant factors that most strongly influence the initial parameters of the grinding process were selected (Table 2).

Table 2

The list of variable factors

\begin{tabular}{|c|c|c|l|}
\hline Factors & Marking & $\begin{array}{c}\text { Area of the } \\
\text { experiment }\end{array}$ & \multicolumn{1}{c|}{ Explanation } \\
\hline $\begin{array}{c}\text { Beet } \\
\text { content, } \\
\%\end{array}$ & $x_{1}$ & $5 \ldots 15$ & $\begin{array}{l}\text { The limits of factor change are } \\
\text { chosen without the minimum }(2,5) \\
\text { and maximum }(22,5) \text { possible values }\end{array}$ \\
\hline $\begin{array}{c}\text { Grain } \\
\text { content, } \\
\%\end{array}$ & $x_{2}$ & $85 \ldots 95$ & $\begin{array}{l}\text { The lower and upper levels of the } \\
\text { factor are selected for technological } \\
\text { reasons and correspond to the limit } \\
\text { of change during the use of the } \\
\text { extruder }\end{array}$ \\
\hline $\begin{array}{c}\text { Producti- } \\
\text { vity, } \mathrm{kg} / \mathrm{h}\end{array}$ & $x_{3}$ & $10-25$ & $\begin{array}{l}\text { The limits of factor change are } \\
\text { determined by previous experiments }\end{array}$ \\
\hline
\end{tabular}

The coding factors and the choice of intervals for their variation are shown in table 3. To obtain a mathematical model of the process described by the second-order polynomial, a three-factor rotatable three-level plan of the BoxWilson for three factors, which is more economical in number of experiments and has their properties, compared to orthogonal and rotatable ones.

Table 3

Encoding of factors and choice of intervals of their variation

\begin{tabular}{|l|c|c|c|}
\hline Designation of factors & $\boldsymbol{x}_{\boldsymbol{1}}$ & $\boldsymbol{x}_{\mathbf{2}}$ & $\boldsymbol{x}_{\mathbf{3}}$ \\
\hline Name of factors & Beet content, $\%$ & $\begin{array}{c}\text { Grain content, } \\
\%\end{array}$ & $\begin{array}{c}\text { Productivity, } \\
\mathrm{kg} / \mathrm{h}\end{array}$ \\
\hline Basic level & 8 & 85 & 15 \\
\hline Variation interval & 5 & 5 & 5 \\
\hline Upper level factor & 15 & 95 & 25 \\
\hline Lower level factor & 5 & 80 & 10 \\
\hline Response function & \multicolumn{3}{|c|}{ y-energy consumption of the extrusion process } \\
\hline
\end{tabular}


The hallmark of the plan is that some factors are at zero levels. The design parameters of the extruder were in accordance with the design of the experiment.

Using STATISTICA for Windows, regression coefficients were obtained and mathematical model of energy intensity of feed extruding process $y$ as a function of beet content $\mathrm{x}_{1}$, grain quantity $\mathrm{x}_{2}$ and extruder productivity $\mathrm{x}_{3}$, which can be written as a second-order polynomial:

$$
\begin{aligned}
y= & 4,700165-0,703805 x_{1}-0,297750 x_{2}-0,038090 x_{3}+ \\
+ & 0,001279 x_{1} x_{3}+0,021375 x_{1} x_{2}+0,001000 x_{2} x_{3}+ \\
& +0,035609 x_{12}+0,018750 x_{22}+0,000247 x_{32} .
\end{aligned}
$$

Finalloss: $\mathrm{R}=0.99545$ Varianceex plained: $99.092 \%$.

The correlation coefficient of the results of the calculations of the polynomial model (2) is equal to $\mathrm{R}=0,99545$, which indicates a sufficiently accurate description of the obtained model of the real process of feed extrusion. The mathematical model obtained also determines the significance of the influence on the dependent variable of both the factors of the experiment and their products. Thus, the energy intensity of the extrusion process is significantly influenced by factor $x_{1}$ than factors $x_{2}$ and $x_{3}$.

The graphical representation of the model obtained as a function of the factors $x_{1}-x_{2}, x_{1}-x_{3}, x_{2}-x_{3}$ can be obtained as a square surface of the energy response of the feed extrusion process (Figure. 1-2).
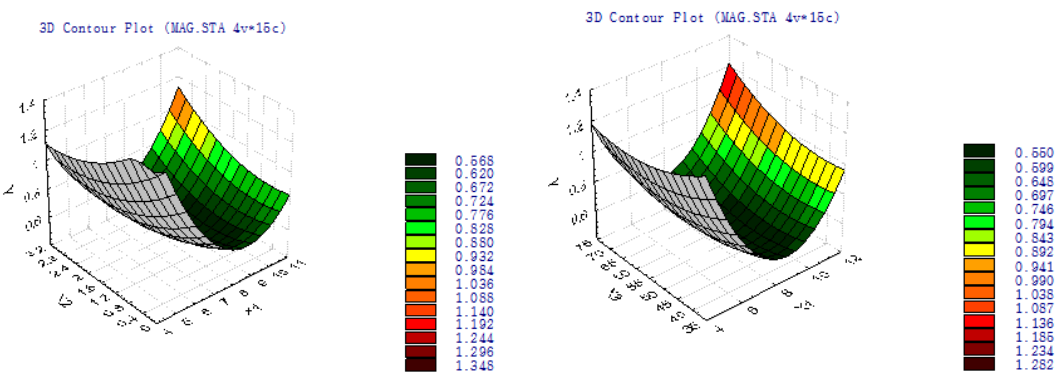

Figure 1. Polynomial energy response surface feed extrusion process as a function of factors $x_{1}-x_{2}, x_{1}-x_{3}$ 


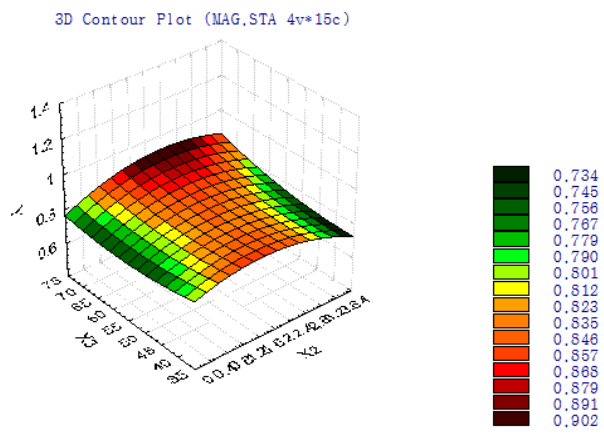

\section{Figure 2. The polynomial surface of the energy response of the feed extrusion process as a function of the factors $x_{2}-x_{3}$}

Graphical analysis of the model showed that the optimal value of the parameters corresponding to the minimum energy consumption of the feed extrusion process is $\mathrm{y}=0,480 \ldots 0,568 \mathrm{~kJ} / \mathrm{kg}$, are within: beet content $x_{I}=8 \%$, grain amount $x_{2}=92 \%$, productivity, $\mathrm{kg} / \mathrm{h} . x_{3}=48 \ldots 52 \mathrm{~kg} / \mathrm{h}$.

Conclusion. It is proved that vegetables are a valuable raw material for the production of compound feed and analysis of the model showed that the optimal value of the parameters corresponding to the minimum energy consumption of the feed extrusion process is $\mathrm{y}=0,480 \ldots 0,568 \mathrm{~kJ} / \mathrm{kg}$, are within: beet content $x_{I}=$ $8 \%$, grain amount $x_{2}=92 \%$, productivity, $\mathrm{kg} / \mathrm{h} . x_{3}=48 \ldots 52 \mathrm{~kg} / \mathrm{h}$.

\section{References:}

1. Afanasyev, V. A. (2002). Teoriya i praktika spetsialnoy obrabotki zernovyih komponentov $v$ tehnologi kombikormov [Theory and practice of special treatment of grain components in feed technology]. Voronezh. (in Russian)

2. Zasyha, T. V. (1997). Novi dyspersni mineraly u tvarynnytstvi [New dispersed minerals in animal husbandry]. Vinnytsia. (in Ukrainian)

3. Egorov, B. V. (2011). Tekhnolohiia vyrobnytstva kombikormiv [Technology of mixed fodder production]. Odesa. (in Ukrainian)

4. Okrushko, S. E. (2019). The influence of the growth regulator Mars EL on the formation of yield hybrids of table beet. Young scientist. No. 9. Pp. 132-137. (in Ukrainian)

5. Stolyarchuk, P. Z. (1986). Zahotivlia kormiv $i$ normovana hodivlia silskohospodarskykh tvaryn [Preparation of feed and normalized feeding of farm animals]. Lviv. (in Ukrainian)

6. Shapovalenko, O. I. (2000). Proizvodstvo kombikormov na Ukraine [Mixed fodder production in Ukraine]. Kiev. (in Ukrainian)

7. Shapovalenko, O. I., Yevtushenko, O. O., \& Kozhevnikova, M. I. (2019). Investigation of feed mixtures based on oil and grain raw materials and sodium and potassium hydroxides. Young scientist. No. 6. Pp. 156-161. (in Ukrainian) 